\title{
SEROPREVALENCE OF HEPATTIS B VIRUS AND HEPATITIS C VIRUS IN MONTE NEGRO IN THE BRAZILIAN WESTERN AMAZON REGION
}

\author{
Marcelo El Khouri, Leandro Savoy Duarte, Rafael Bernadon Ribeiro, Luis \\ Fernando Ferraz da Silva, Luis Marcelo Aranha Camargo, Vera Aparecida dos \\ Santos, Marcelo Nascimento Burattini and Carlos Eduardo Pereira Corbett
}

KHOURI ME et al. Seroprevalence of hepatatis B virus and hepatitis C virus in Monte Negro in the Brazilian western Amazon region. CLINICS 60(1):29-36, 2005.

PURPOSE: This study was carried out in Monte Negro (state of Rondônia), a village in the Brazilian western Amazon region, where a University of São Paulo Medical School program for medical student training in rural assistance took place. It aimed to determine the prevalence of hepatitis B virus and hepatitis $\mathrm{C}$ virus, to investigate risk factors for infection, and to evaluate the State immunization program against hepatitis B virus in the region.

METHODS: The study is a cross-sectional seroprevalence survey, comprising 267 volunteers who answered a comprehensive questionnaire and had blood samples collected, which were analyzed in São Paulo for the presence of antibodies against hepatitis B virus (Hbs Ag, anti-Hbs, and anti-Hbc) and hepatitis $\mathrm{C}$ virus using commercial kits. Data were stored in a specific data bank, and the association between seropositivity and potential risk factors was analyzed by means of uni-, bi-, and multi-variate analysis, considering $\pm 5 \%$.

RESULTS: The seroprevalence of hepatitis B virus was $61.79 \%$ and of hepatitis C virus was $0.38 \%$. Statistical analysis on the data bank showed that the prevalence of hepatitis B virus rose significantly with age, especially after adolescence. Infection was higher in those coming from outside the state of Rondônia. Exposure to vaccination against hepatitis B virus was higher in younger individuals and in those who were born in Rondônia.

CONCLUSION: Monte Negro is a highly endemic region for hepatitis B virus but not for hepatitis C virus. Our results also provide indirect evidence indicating a significant improvement in the immunization program in Rondônia in recent years.

KEYWORDS: Brazil. Amazon region. hepatitis B. Hepatitis C. Seroprevalence. Immunization programs.

Hepatitis B is a worldwide disease with around 300 million infected individuals-with a prevalence of $5 \%$ to $10 \% .^{1,2}$ The hepatitis B virus (HBV) is transmitted through body fluids such as semen, saliva, sweat, tears, or breast milk. The currently acknowledged risk factors for infection by the HBV are sexual promiscuity, intravenous drug abuse, blood and derivatives transfusions, hemodialysis, and needle ac-

From the Laboratory of Infectious Disease and Central Laboratory Division, Hospital das Clínicas, Faculty of Medicine, University of São Paulo - São Paulo/SP, Brazil.

E-mail: ccorbett@usp.br

Received for publication on May 09, 2004.

Accepted for publication on October 22, 2004. cidents among health-care professionals. HBV infection can cause asymptomatic disease or acute or chronic hepatitis. The latter may evolve to cirrhosis, fulminant hepatitis with massive necrosis, or hepatocellular carcinoma. ${ }^{3}$

According to the Brazilian Ministry of Health ${ }^{4}$, the national prevalence of $\mathrm{HBV}$ infection is $7.9 \%$. In the Amazon region, the prevalence is only slightly higher than in the rest of the country (8\%).

The Brazilian government implemented a national immunizations program in 1992, which gradually initiated vaccinations against hepatitis $B$ in the Amazon region. In this region the vaccine is administered to everyone up to 20 years of age in a 3 -dose scheme. The national vaccine 
coverage is $5.64 \%$, and in the state of Rondônia, it is $37.94 \% .^{5}$

On the other hand, although less prevalent than hepatitis $\mathrm{B}$, hepatitis $\mathrm{C}$ is the main cause of chronic hepatitis (20\%-25\% of the chronic hepatitis) worldwide . ${ }^{6-8}$ Currently, it is considered as one of the public health priorities by the WHO, ${ }^{8,9}$ with an estimated prevalence of 170 million chronic infections in the world. ${ }^{8}$ Percutaneous inoculation and blood transfusions are the main modes of transmission. In fact, the hepatitis $\mathrm{C}$ virus (HCV) is the main agent of posttransfusion hepatitis $(80 \%-90 \%) .{ }^{9,10}$ There are no official data on the prevalence of HCV in Brazil.

The aim of this study was to evaluate the seroprevalence of HBV and HCV in Monte Negro, a country village located in the state Rondônia, which is part of the Amazon region, which is endemic for $\mathrm{HBV}$. We also intended to evaluate the vaccine coverage for HBV in Monte Negro.

\section{PATIENTS AND METHODS}

Monte Negro (Fig. 1) is a small village in the state of Rondônia in the Western Amazon region of Brazil. It is located aproximately $250 \mathrm{~km}$ away from the state capital Porto Velho, with a population of 12,086 inhabitants, $60 \%$ of which live in the rural area. Since 1997, a nucleus for field studies of the University of São Paulo (USP) has been installed in the village of Monte Negro, when a new familyhealth program was implemented with technical assistance from USP. In December 2000, the village was visited by the "Bandeira Científica", a program sponsored by the Medical School of the University of São Paulo (FMUSP) for student training in rural assistance, during which health counseling and research activities were conducted in addition to health assistance to the population. The present study refers to one of these research activities.

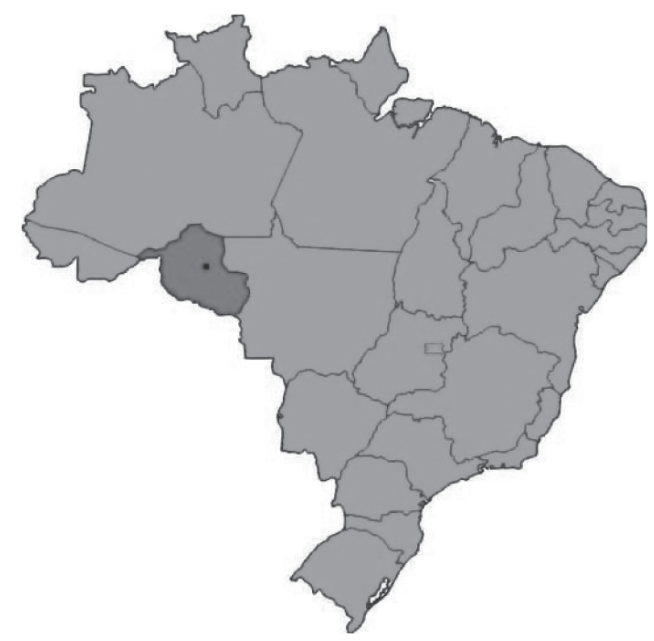

Figure 1 - The state of Rondônia (shaded) and Monte Negro (black dot).
The study consisted of a cross-sectional seroepidemiological study to assess the risk factors for infection with HBV and HCV in Monte Negro. The study protocol was approved by the Ethics Committee for Research Protocols of the University of São Paulo Medical School.

Throughout the "Bandeira Científica", 25 bases were created where patients were recruited by health-care agents for medical consultations. Each base covered a certain region of the village. People who were around the bases were invited to join the study. Participants were sorted randomly, stratified according to gender and age, and asked to sign an informed consent form.

Two hundred and sixty seven (267) individuals agreed to participate in the study. The interview comprised questions on gender, age, race, state in which the participant was born, marital status, time of residency in Monte Negro, occupation, level of formal education, annual income, number of residents per house, type of housing, and smoking and drinking habits. Blood samples were collected using a Vacutainer ${ }^{\circledR}$ system. The material was transported to São Paulo in dry ice and kept at $-70{ }^{\circ} \mathrm{C}$ until laboratory analysis.

Serological examinations for HBV were performed by standard ELISA techniques with commercial kits from ROCHE on COBAS ${ }^{\circledR}$ CORE II EIA, testing sera against HBs$\mathrm{Ag}$, anti-HBs, and anti-HBc. We used anti-HBc as a surrogate for infection with $\mathrm{HBV}$ on the risk factor analysis. The ELISA test for HCV was performed using COBAS ${ }^{\circledR}$ CORE Anti-HCV EIA, ROCHE. Positive cases were also analyzed by AXSYM ${ }^{\circledR}$ HCV version 3.0, ABBOTT. The positivity criterion was the presence of positive results with both kits (ROCHE and ABBOTT), since the ELISA test has a low positive predictive value. ${ }^{11,12}$

Data was stored in an Excel $2000^{\circledR}$ worksheet comprising information from the questionnaires and the serology results. Statistical analysis consisted of uni- and bivariate analysis, as well as a multivariate analysis by logistic regression. We used the software Statistica $4.5^{\circledR}$ and chose $5 \%$ as the significance level.

\section{RESULTS}

The population studied was composed of 149 (55.6\%) females and $119(44.4 \%)$ males. Ages ranged from 5 to 81 years, with a median age of 34 years $(34.2 \pm 18.9$, mean \pm $\mathrm{SD})$. White people were most frequently found in our study (47.0\%), followed by mulattos $(36.6 \%)$, black (13.1\%), and yellow $(0.4 \%)$ people. The mean time of residency in the city was 13.1 years. Only $28.0 \%$ of the group was from Rondônia originally. The mean annual income was US\$1142, earned usually by 2 people, with a total of 4.5 members per house. In the study, $70 \%$ of the people had 
some education up to middle school (8 years of studying), and approximately half of them worked in agriculture.

The serologic results are summarized in Table I. The seroprevalence of $\mathrm{HCV}$ - determined by the presence of 2 simultaneously positive EIA (enzymatic immunologic assay) results using commercial kits from ROCHE and $\mathrm{AB}$ BOT - was only 1 case $(0.37 \%)$. However, 5 samples were $\mathrm{COBAS}^{\circledR}$ CORE Anti-HCV EIA positive and $\mathrm{AXSYM}^{\circledR} \mathrm{HCV}$ version 3.0 negative. Thus, no statistical analysis was done for this variable.

Table 1 - Summary of Hepatitis B virus (HBV) and Hepatitis $\mathrm{C}$ virus (HCV) serologic results.

\begin{tabular}{llll}
\hline & $N(\%)$ & Positive $(\%)$ & Negative $(\%)$ \\
\hline Anti-HCV & $261(100)$ & $1(0.38)$ & $260(99.61)$ \\
Anti-HBc & $267(100)$ & $165(61.79)$ & $102(38.21)$ \\
HbsAg & $267(100)$ & $13(4.86)$ & $254(95.14)$ \\
Anti-HBs & $264(100)$ & $172(65.15)$ & $92(34.85)$ \\
Anti-HBc + and HbsAg + & $267(100)$ & $9(3.37)$ & $258(96.63)$ \\
Anti-HBc - and HbsAg + & $267(100)$ & $4(1.50)$ & $263(98.5)$ \\
Any positive seromarker & $267(100)$ & $201(75.28)$ & $66(24.71)$ \\
\hline
\end{tabular}

The seroprevalence of HBV (total anti-HBc positive) was 165 (61.8\%). Tables II and III correlate anti-HBc with anti-HBs and HBsAg with anti-HBs, respectively. Among these anti-HBc patients, 137 (51.9\%) were immune to the virus (anti-HBs positive and HBsAg negative). In the population studied, 13 cases $(4.86 \%)$ were $\mathrm{HBsAg}$ positive, indicating active infection. Four cases $(1.52 \%)$ were positive to both HBsAg and anti-HBs, whereas 19 cases $(7.06 \%)$ were only anti-HBc positive (with $\mathrm{HBsAg}$ and anti-HBs nega-
Table 2 - Correlation between Anti-HBc and Anti-HBs prevalence.

\begin{tabular}{llll}
\hline & Anti-HBs & Total \\
\hline Anti-HBc & $+(\%)$ & $-(\%)$ & $(\%)$ \\
+ & $137(51.89)$ & $26(9.85)$ & $163(61.74)$ \\
- & $35(13.26)$ & $66(25.00)$ & $101(38.26)$ \\
Total & $172(65.15)$ & $92(34.85)$ & 264 \\
\hline
\end{tabular}

Table 3 - Correlation between HBsAg and Anti-HBs.

\begin{tabular}{llll}
\hline & Anti-HBs & Total \\
\hline HbsAg & $+(\%)$ & $-(\%)$ & $(\%)$ \\
+ & $4(1.52)$ & $7(2.65)$ & $11(4.17)$ \\
- & $168(63.64)$ & $85(32.30)$ & $253(95.83)$ \\
Total & $172(65.15)$ & $92(34.85)$ & 264 \\
\hline
\end{tabular}

tive). 35 subjects (13.3\%) were anti-HBc negative and antiHBs positive, suggesting immunization after vaccines.

The risk analysis for the presence of anti-HBc antibodies is summarized in Table IV. In Figure 2 we show that there was no gender difference in the prevalences of anti-HBs, anti-HBc, $\mathrm{HbsAg}$, or anti-HCV. In Figure 3 we show that the age-related prevalence of anti-HBc did not differ significantly between men and women.

Table IV shows an increasing risk for anti-HBc with age $(P<0.0001)$, time of residence in Monte Negro $(P<0.001)$, and being born outside Rondônia $(P<0.0001)$. On the other hand, being a student implied in protection against infection with $\mathrm{HBV}(P=0.018)$. However, this effect disappeared when it was stratified by age, since students were mostly

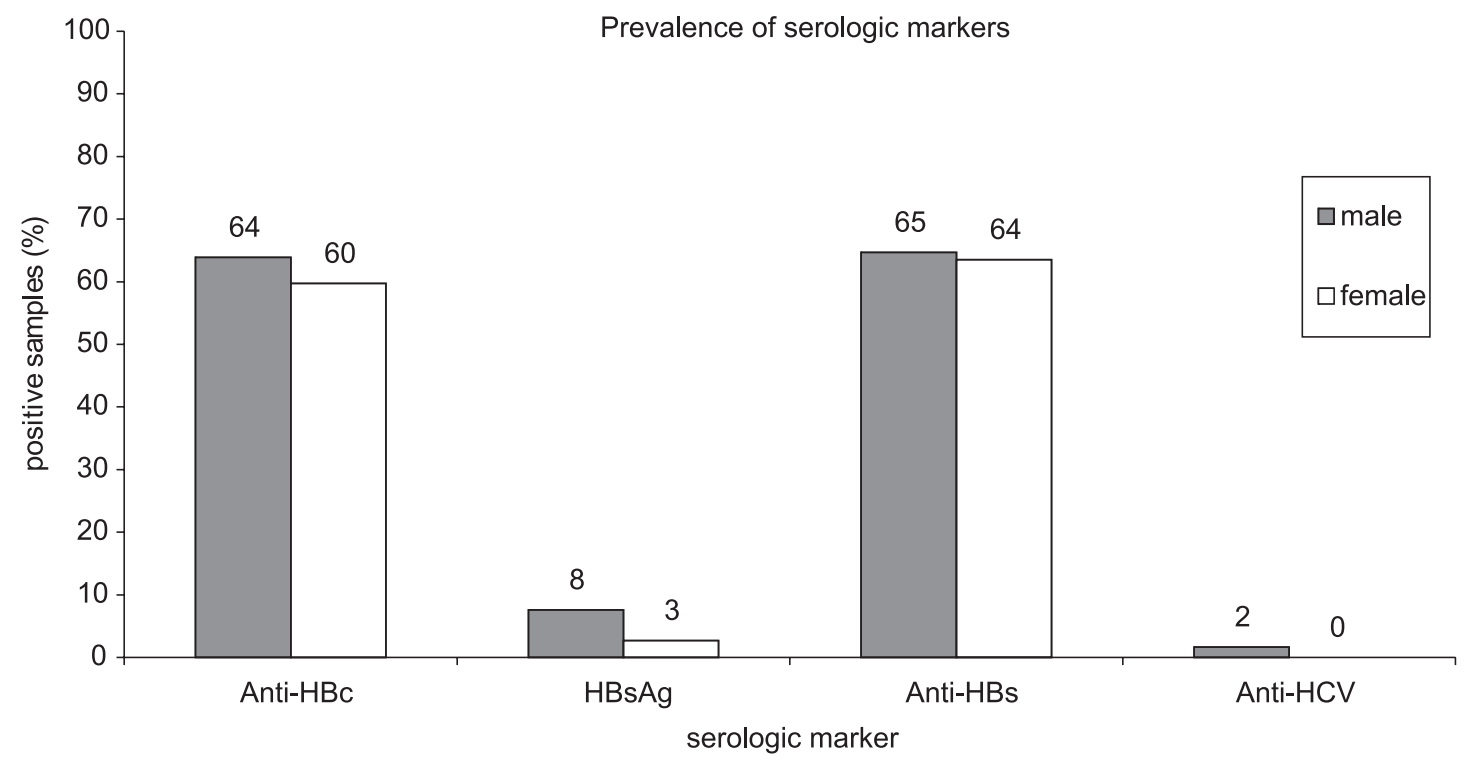

Figure 2 - Positive serologic markers by gender. 


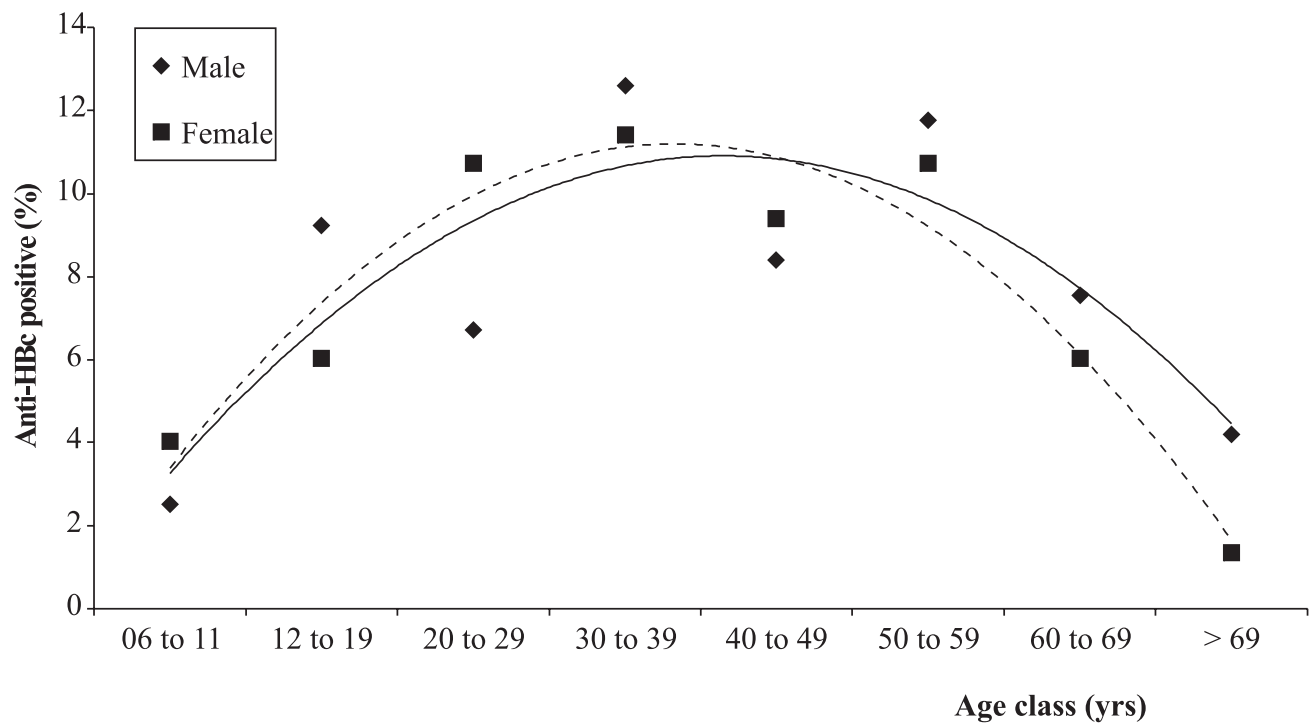

Figure 3 - Prevalence of Hepatitis B virus (HBV), as indicated by anti-HBc antibodies, stratified by gender and age with their trendlines.

children and young people, who should not yet have been infected with the virus. No other variables had any statistical significance in relation to antiHBc.

The multivariate analysis for anti-HBc (Table V) included gender and the variables with a $P$ value $<0.100$ in the bivariate analysis. After this analysis, the only variables significantly associated with anti-HBc were age and state of birth.

Further bivariate analysis of these significant variables described in Table IV was performed: the prevalence of antiHBs was determined in anti-HBc negative individuals, as an attempt to evaluate the immunization program in the state of Rondônia. Table VI displays only the significantly associated variables and shows that individuals younger than 12 years and those born in Rondônia were more exposed to vaccine against HBV than their counterparts.

\section{DISCUSSION}

This prevalence study was intended to evaluate the number of subjects infected with $\mathrm{HBV}$ and $\mathrm{HCV}$, as well as to identify the current clinical situation of the anti-HBc positive population. It was also part of this study to determine a correlation between the data obtained from the population and the results of the study.

Throughout the Bandeira Cientifica project, 25 bases were created where patients were recruited for medical consultations by health-care agents. Each base covered a certain region of the village. While seeking treatment at the bases, the population in general was invited join the study. Therefore, although it is known that hepatits $\mathrm{B}$ and $\mathrm{C}$ are almost always asymptomatic, this study may include a greater proportion of sick individuals, since we only had access to those people who came to the bases, mostly seeking medical assistance (Table IV). The volunteers were recruited randomly without knowledge of either their reason for seeking treatment there, or their symptoms, though an effort was made to include the same number of individuals according to gender and age. Monte Negro is a recently settled area, so only $27.7 \%$ of the group was originally from Rondônia; the mean time of residence in the city was 12.8 years. The mean family annual income was very low, round $\mathrm{U} \$ 1142.00$, earned usually by 2 people, with a total of 4.5 members per house. There was a general lack of sanitary conditions, with only $1.56 \%$ having garbage collection, $4.85 \%$ having indoor plumbing, with more than $30 \%$ dumping their sewage out in the open or in rivers. Education was also deficient, with $70 \%$ having some education only up to elementary school level. Approximately half of the population worked in agriculture.

The prevalence of HBV (positive anti-HBc) found in Monte Negro (61.8\%) is much higher than in other parts of Brazil $(7.9 \%)^{13}$ and than that found in an indigenous population of Rondônia (35\%). ${ }^{14}$ The results are equivalent to those found in a population of Albanese refugees in Apulia, South Italy $(62.1 \%) .{ }^{15}$ In Latin America, ${ }^{13}$ the highest rates were found in the Dominican Republic (21.4\%), followed by Venezuela (3.2\%), and Argentina (2.1\%). The lowest rates were found in Mexico (1.4\%) and Chile $(0.6 \%)$. The prevalence rates found in different regions of Brazil may be as high as $21 \%$ in Manaus or as low as $1.2 \%$ in Fortaleza. The Amazon region is considered highly endemic for HBV. Monte Negro may therefore be labeled a highly endemic site for HBV infection. We were not able to develop a de- 
Table 4 - Descriptive and Bivariate analysis for Anti-HBc positive individuals.

\begin{tabular}{|c|c|c|c|c|}
\hline \multirow{2}{*}{$\begin{array}{l}\text { Variables } \\
\text { Gender }\end{array}$} & \multicolumn{2}{|l|}{ Descriptive analysis } & \multicolumn{2}{|c|}{ Bivariate analysis for anti-HBc +} \\
\hline & $\begin{array}{l}n(\%) \\
\text { Male }(\%) \\
\text { Female }(\%)\end{array}$ & $\begin{array}{l}n(\% \text { within category) } \\
119(44.40) \\
149(55.59)\end{array}$ & $\begin{array}{l}P \text { value } \\
76(64.41) \\
89(59.73)\end{array}$ & 0.513 \\
\hline Skin Color & $\begin{array}{l}\text { White }(\%) \\
\text { Yellow }(\%) \\
\text { Black }(\%) \\
\text { Mulatto }(\%)\end{array}$ & $\begin{array}{l}126(47.01) \\
1(0.37) \\
35(13.05) \\
98(36.56)\end{array}$ & $\begin{array}{l}76(60.32 \%) \\
1(100 \%) \\
24(68.57 \%) \\
61(62.89 \%)\end{array}$ & 0.702 \\
\hline Age & $\begin{array}{l}\leq 12 \mathrm{yrs} \\
>12 \mathrm{yrs}\end{array}$ & $\begin{array}{l}44(16.79) \\
218(83.20)\end{array}$ & $\begin{array}{l}11(25 \%) \\
153(70.51 \%)\end{array}$ & 0.000 \\
\hline Time of residence in Monte Negro & $\begin{array}{l}\leq 5 \mathrm{yrs} \\
>5 \mathrm{yrs}\end{array}$ & $\begin{array}{l}44(17.89) \\
202(82.11)\end{array}$ & $\begin{array}{l}18(40.91 \%) \\
138(68.32 \%)\end{array}$ & 0.001 \\
\hline Income contributors & $\begin{array}{l}\leq 3 \text { contributors } \\
>3 \text { contributors }\end{array}$ & $\begin{array}{l}213(81.30) \\
49(18.70)\end{array}$ & $\begin{array}{l}130(61.03) \\
34(80.77)\end{array}$ & 0.354 \\
\hline State of birth & $\begin{array}{l}\text { Rondônia (\%) } \\
\text { Other }(\%)\end{array}$ & $\begin{array}{l}75(27.98) \\
186(69.40)\end{array}$ & $\begin{array}{l}29(36.67 \%) \\
121(72.89 \%)\end{array}$ & 0.000 \\
\hline Marital status $(>14$ yrs old $)$ & $\begin{array}{l}\text { Single/divorced/widow }(\%) \\
\text { Married/living together }(\%)\end{array}$ & $\begin{array}{l}44(21.46) \\
161(78.53)\end{array}$ & $\begin{array}{l}28(63.64 \%) \\
118(73.75 \%)\end{array}$ & 0.259 \\
\hline Interviewee's occupation & $\begin{array}{l}\text { Peasant }(\%) \\
\text { Student }(\%) \\
\text { Housewife }(\%) \\
\text { Other }(\%)\end{array}$ & $\begin{array}{ll}150(55.97) \\
15(5.59) \\
63(23.50) \\
10(3.73)\end{array}$ & $\begin{array}{l}101(67.79 \%) \\
4(26.67 \%) \\
39(61.90 \%) \\
6(60 \%)\end{array}$ & 0.018 \\
\hline Interviewee's education & $\begin{array}{l}\text { Illiterate }(\%) \\
\text { Full or partial education up } \\
\text { to Middle School }-8 \text { years } \\
\text { of schooling }(\%) \\
\text { Full or partial education up } \\
\text { to High School }-11 \text { years } \\
\text { of schooling }(\%)\end{array}$ & $\begin{array}{l}50(18.65) \\
191(71.26) \\
5(1.86)\end{array}$ & $\begin{array}{l}35(70 \%) \\
110(57.89 \%) \\
3(60 \%)\end{array}$ & 0.297 \\
\hline Residents per house & $\begin{array}{l}\text { Up to three subjects }(\%) \\
\text { Four or five subjects }(\%) \\
\text { More than six subjects }(\%)\end{array}$ & $\begin{array}{l}84(31.34) \\
116(43.28) \\
66(24.62)\end{array}$ & $\begin{array}{ll}57 & (77.86) \\
63 & (74.88) \\
45 & (68.18)\end{array}$ & 0.888 \\
\hline Annual income & $\begin{array}{l}\text { Up to US\$ } 1015.22(\%) \\
\text { More than US } \$ 1015.22(\%)\end{array}$ & $\begin{array}{l}79(29.47) \\
84(31.34)\end{array}$ & $\begin{array}{l}50(63.29 \%) \\
50(59.52 \%)\end{array}$ & 0.739 \\
\hline Housing & $\begin{array}{l}\text { Own }(\%) \\
\text { Rented }(\%)\end{array}$ & $\begin{array}{l}225(83.95) \\
40(14.92)\end{array}$ & $\begin{array}{l}141(62.95) \\
23(57.5)\end{array}$ & 0.633 \\
\hline Floor & $\begin{array}{l}\text { Soil }(\%) \\
\text { Cement/wood }(\%)\end{array}$ & $\begin{array}{l}43(16.04) \\
225(83.95)\end{array}$ & $\begin{array}{l}26(60.47) \\
139(62.05)\end{array}$ & 0,980 \\
\hline Wall & $\begin{array}{l}\text { Brick-built }(\%) \\
\text { Wood }(\%)\end{array}$ & $\begin{array}{l}18(6.71) \\
246(91.79)\end{array}$ & $\begin{array}{l}15(83.33) \\
147(60)\end{array}$ & 0,866 \\
\hline Garbage & $\begin{array}{l}\text { Collected }(\%) \\
\text { Open sky }(\%) \\
\text { Burnt }(\%)\end{array}$ & $\begin{array}{l}5(1.86) \\
48(17.91) \\
211(78.73)\end{array}$ & $\begin{array}{l}4(80) \\
28(58.33) \\
131(62.38)\end{array}$ & 0,614 \\
\hline Sewage & $\begin{array}{l}\text { Sewage system or latrine }(\%) \\
\text { Open sky/river }(\%)\end{array}$ & $\begin{array}{l}171(63.80) \\
90(33.58)\end{array}$ & $\begin{array}{l}111(64.91) \\
52(58.43)\end{array}$ & 0,373 \\
\hline Water & $\begin{array}{l}\text { In house plumbing (\%) } \\
\text { Pit/mine }(\%)\end{array}$ & $\begin{array}{l}13(4.85) \\
226(84.32)\end{array}$ & $\begin{array}{l}9(69.23) \\
140(61.95)\end{array}$ & 0,815 \\
\hline Alcohol intake & $\begin{array}{l}\text { Yes }(\%) \\
\text { No }(\%)\end{array}$ & $\begin{array}{l}57(21.26) \\
197(73.50)\end{array}$ & $\begin{array}{l}39(69.64) \\
114(57.87)\end{array}$ & 0.151 \\
\hline Type of drinking & $\begin{array}{l}\text { Distilled (\%) } \\
\text { Brewed (\%) } \\
\text { Both }(\%)\end{array}$ & $\begin{array}{l}24(8.95) \\
24(8.95) \\
13(4.85)\end{array}$ & $\begin{array}{l}16(69.57) \\
15(62.5) \\
12(92.31)\end{array}$ & 0.151 \\
\hline Daily dosage & $\begin{array}{l}1 \text { dose }(\%) \\
2 \text { doses }(\%) \\
>2(\%)\end{array}$ & $\begin{array}{l}41(15.29) \\
2(0.74) \\
17(6.34)\end{array}$ & $\begin{array}{l}28(70) \\
1(50) \\
14(82.35)\end{array}$ & 0.479 \\
\hline Length of usage & $\begin{array}{l}<10 \text { yrs }(\%) \\
10 \text { to } 20 \text { yrs }(\%) \\
>20 \text { yrs }(\%)\end{array}$ & $\begin{array}{l}7(2.61) \\
17(6.34) \\
31(11.56)\end{array}$ & $\begin{array}{l}5(71.43) \\
9(52.49) \\
24(80)\end{array}$ & 0.098 \\
\hline
\end{tabular}


Table 4 - cont.

\begin{tabular}{|c|c|c|c|c|}
\hline \multirow{2}{*}{$\frac{\text { Variables }}{\text { Smoking }}$} & \multicolumn{2}{|l|}{ Descriptive analysis } & \multicolumn{2}{|c|}{ Bivariate analysis for anti-HBc +} \\
\hline & $\begin{array}{l}\text { Yes } \\
\text { No and former smokers }\end{array}$ & $\begin{array}{l}37(14.17) \\
224(85.82)\end{array}$ & $\begin{array}{l}25(69.44) \\
134(59.82)\end{array}$ & 0.360 \\
\hline Pack-years ( $\%$ out of yes) & $\begin{array}{l}<6 \\
>5 \text { and }<11 \\
>10 \text { and }<16 \\
>15 \text { and }<21 \\
>20 \text { and }<26 \\
>25\end{array}$ & $\begin{array}{l}13(15.47) \\
11(13.09) \\
6(7.14) \\
6(7.14) \\
11(13.09) \\
37(44.04)\end{array}$ & $\begin{array}{l}8(61.54) \\
10(90.91) \\
3(50) \\
4(66.67) \\
8(72.76) \\
30(83.33)\end{array}$ & 0,264 \\
\hline $\begin{array}{l}\text { Reason for being around bases } \\
\text { and thus participating in the study }\end{array}$ & $\begin{array}{l}\text { Medical consultation }(\%) \\
\text { Other }(\%)\end{array}$ & $\begin{array}{l}197(73.50) \\
59(22.01)\end{array}$ & $\begin{array}{l}126(49.41) \\
32(12.55)\end{array}$ & 0.214 \\
\hline
\end{tabular}

Table 5 - Multivariate analysis for variables associated with Anti-HBc prevalence.

\begin{tabular}{lll}
\hline Variables & $\begin{array}{l}\text { Regression } \\
\text { Coefficient } \pm \text { SD }\end{array}$ & P value \\
\hline Gender & $-0.289 \pm 0.072$ & 0.691 \\
Age & $0.196 \pm 0.075$ & 0.010 \\
State of birth & $0.179 \pm 0.77$ & 0.020 \\
Time of residency in Monte Negro & $0.127 \pm 0.065$ & 0.054 \\
Interviewee's occupation & $0.009 \pm 0.074$ & 0.903 \\
\hline
\end{tabular}

Table 6 - Anti-HBs positive seromarker in anti-HBc negative subjects.

\begin{tabular}{lllll}
\hline Variables & & & \multicolumn{3}{l}{$\begin{array}{l}\text { Anti-HBs }+ \\
n(\%)\end{array}$} \\
& & \multicolumn{3}{c}{$\begin{array}{l}n \text { of within P value } \\
\text { the category) }\end{array}$} \\
\hline State of birth & Rondônia $(\%)$ & $46(46.94)$ & $24(52.17)$ & 0.001 \\
& Other (\%) & $52(53.06)$ & $10(19.61)$ & \\
\hline Age & $\leq 12$ yrs & $33(34.02)$ & $20(60.61)$ & 0.000 \\
& $>12$ yrs & $64(65.98)$ & $14(22.22)$ & \\
\hline
\end{tabular}

finitive explanation for this. The risk analysis shows an increasing risk with age and for those who were born outside of Rondônia. The fact that HBV is sexually transmitted, associated with the high prevalence of infected people from other states $(72.89 \%)$ moving to that region and with a particular precocity of sexual activity, low access to the healthcare system, and inadequate sanitation could offer a plausible hypothesis for the high HBV prevalence seen in that region.

We detected only $13.3 \%$ of the participants as poten- tially immunized against HBV (negative anti-HBc and positive anti-HBs), which should be contrasted with a reported rate of vaccine coverage of $37.94 \%$ in the state of Rondônia, according to data from Programa NACIONAL DE IMUNIZAÇõES (NIP). ${ }^{6}$ Nevertheless, NIP can now be regarded as more effective in Rondônia, since we observed that young people and those locally born have a presumably higher vaccination coverage, as shown in Table VI. In addition, our findings that being born outside the State of Rondônia seems to be associated with a higher prevalence of HBV could be indirect evidence of the effectiveness of NIP in this state.

The prevalence of $0.37 \%$ of hepatitis $\mathrm{C}$ (anti-HCV) is much less than the worldwide estimate of $3 \%$, according to the WHO. ${ }^{9}$ Just as for $\mathrm{HBV}$, there is great variation in the prevalence rates in different regions, being as low as $0.3 \%$, in a population of Albanese refugees in South Italy, ${ }^{15}$ around $1.8 \%$ in the USA, ${ }^{8,16}$ to $20 \%$ in the district of Yamagata in Japan, ${ }^{17}$ - a region that was considered endemic for hepatitis C from 1967 to 1972 , but with no established transmission route — and as high as $24.3 \%$ in a rural Egyptian community in the Nile Delta, ${ }^{18}$ associated with schistosomiasis therapy by intramuscular injections. Although there are no official data on the prevalence of $\mathrm{HCV}$ in Brazil, the seroprevalence found in an indigenous population in Rondônia was $1.7 \%{ }^{14}$ while in a group in the South Amazon region it was $2.4 \%,{ }^{19}$ which was related to intravenous drug abuse.

Thus, our study shows that Monte Negro is a highly endemic area for $\mathrm{HBV}$, with a surprisingly low prevalence of $\mathrm{HCV}$. We also found an effective improvement in the immunizations program in this state. 
KHOURI ME e col. Soroprevalência de Hepatite B e Hepatite C em Monte Negro, Rondônia, Região Amazônica Ocidental Brasileira. CLINICS 60(1):29-36, 2005.

OBJETIVOS: O presente estudo foi realizado em Monte Negro, Rondônia, Amazônia Oriental, onde um projeto de acadêmicos de Medicina da Universidade de São Paulo promoveu assistência médica à população rural. $\mathrm{O}$ objetivo foi determinar a soroprevalência de Hepatite B e Hepatite C, investigar os fatores de risco para sua infecção e avaliar o status imunológico vacinal contra Hepatite B nesta região.

MÉTODOS: O estudo é uma pesquisa de corte transversal de soroprevalência, compreendendo 267 voluntários que tiveram suas amostras sanguíneas coletadas após preenchimento de um questionário. As amostras foram analisadas em São Paulo usando kits comerciais pesquisando anticorpos contra Hepatite B (AgHBs, Anti-HBs e Anti-HBc) e Hepatite C . Um banco de dados montado através do questionário foi analisado em relação aos resultados sorológicos com testes uni-, bi-, e multivariado, considerando $\pm=5 \%$.

RESULTADOS: A soroprevalência do VHB encontrada foi de $61.79 \%$ e do Hepatite C, $0.38 \%$. A análise dos possíveis fatores de risco mostrou que a prevalência de Hepatite B aumenta com a idade, especialmente após a adolescência, além de ser maior em aqueles nascidos em Rondônia. A exposição à vacinação contra Hepatite $\mathrm{B}$ foi maior em indivíduos jovens e aqueles nascidos em Rondônia.

CONCLUSÃO: Monte Negro é uma região altamente endêmica para Hepatite B , mas não para Hepatite C . Ademais, os resultados obtidos evidenciam uma significativa melhora no programa de imunizações em Rondônia nos anos recentes.

UNITERMOS: Brasil. Região Amazônica. Hepatite B. Hepatite C. Soroprevalência. Programa de imunização.

\section{REFERENCES}

1. Zuckerman JN, Zuckerman AJ. Hepatitis viruses and TT virus. In:Leidingan JGG, Warrel DA. Concise Oxford Textbook of Medicine. 1st ed. New York: Oxford Press; 2000. pp. 1553-5.

2. Maddrey WC. Hepatitis B - an important public health issue. Clin Lab 2001;47:51-5.

3. DiMarco V, Lo Iacono O, Camma C, Vaccaro A, Giunta M, Martorana G, et al. The long-term course of chronic hepatitis B. Hepatology 1999;30:257-64.

4. Brazilian Ministery of Health. Fundação Nacional de Saúde. Centro Nacional de Epidemiologia Indicadores e Dados Básicos 1998.

5. Brazilian Ministery of Health. National Immunization Program. Sistema de Informações do Programa Nacional de Imunizações (SI-PNI). Indicadores e Dados Básicos 1998.

6. Bonkovsky HL, Metha S. Hepatitis C: a review and update. J Am Acad Dermatol 2001;44:159-82.

7. Feng X. Hepatitis C infection: a review. Lippincotts Prim Care Pract 1999;3:345-53.

8. WHO. Global surveillance and control of hepatitis C. Report of WHO Consulation organized in colaboration with the Viral Hepatitis Prevention Board, Antwerp, Belgium. J Viral Hepat 1999;6:35-47.

9. Lavanchy D, Gavinio P. Hepatitis C. Can J Gastroenterol 2000;14:67B-76B
10. Crawford J. The Liver and the Biliary Tract. In: Cotran RS, Kumar V, Collins T. Pathologic basis of disease - Robbins. 4th ed. Philadelphia: Saunders, 1999. pp. 857-62.

11. Dos Santos VA, Azevedo RS, Camargo ME, Venâncio AFA. Serodiagnosis of hepatitis $\mathrm{C}$ virus: effect of new evaluation of cutoff values for enzyme-linked immunosorbent assay in Brazilian patients. AJCP 1999;112:418-24.

12. Kim YS, Lee HS, Ahn YO. Factors associated with positive predictability of the anti-HCV ELISA method with confirmatory RT-PCR. J Korean Med Sci 1999;14:629-34.

13. Tanaka J. Hepatitis B epidemiology in Latin America. Vaccine 2000;18:S17-S19.

14. Ferrari JO, Ferreira MU, Tanaka A, Mizokami M. The seroprevalence of hepatitis $\mathrm{B}$ and $\mathrm{C}$ in an Amerindian population in the southwestern Brazilian Amazon. Revista da Sociedade Brasileira de Medicina Tropical 1999;32:299-302.

15. Chironna M, Germinario C, Lopalco PL, Quarto M, Barbuti S. $\mathrm{HBV}, \mathrm{HCV}$ and HDV infections in Albanian refugees in Southern Italy (Apulia region). Epidemiol and Infect 2000; 125: 163167.

16. Willians I. Epidemiology of hepatitis C in the United States. Am J Med 1999; 107:2S-9S. 
17. Yoshii E, Shinzawa H, Saito T, Shao L, Kuboki M, Saito K, Togashi $\mathrm{H}$, Takahashi T, Mizokami M. Molecular epidemiology of hepatitis $\mathrm{C}$ virus infection in an area endemic for communityacquired acute hepatitis C. Tohoku J Exp Med 1999;188:3116.

18. Abdel-Aziz F, Habib M, Mohamed MK, Abdel-Hamid M, Gamil F, Madkour S, Mikhail NM, Thomas D, Fix AD, Strickland GT, Anwar W, Sallam I. Hepatitis C virus (HCV) infection in a community in the Nile Delta: population description and HCV prevalence. Hepatology 2000;32:111-5.
19. Souto FJ, Fontes CJ, Martelli CM, Turchi MD, Martins RM, Andrade AL. Hepatitis C virus prevalence among an immigrant community to the southern Amazon, Brazil. Mem Inst. Oswaldo Cruz 1999;94:719-23. 